\title{
Modified PIRO (predisposition, insult, response, organ dysfunction) severity score as a predictor for mortality of children with pneumonia in Hasan Sadikin Hospital, Bandung, Indonesia
}

\author{
Vebri Valentania, Dadang H. Somasetia, Dany Hilmanto, Djatnika Setiabudi, Heda Melinda N. Nataprawira \\ Department of Child Health, Faculty of Medicine, Universitas Padjadjaran/Dr. Hasan Sadikin General Hospital, Bandung, \\ Indonesia
}

Background: Clinical manifestations for pneumonia vary from mild to severe. The PIRO model (predisposition, insult, response, organ dysfunction) was used as scoring system to determine severity of sepsis and pneumonia in adult patients. The PIRO model was modified for sorting the severity of pneumonia in children and predicting its risk of mortality.

Methods: An ambispective cohort study of pneumonia patients aged 1 month to $\leq 18$ years admitted over the period from May to September 2020. Data were collected from history, physical examination, laboratory examination, and chest radiography. Based on bivariate analysis $(\mathrm{p}<0.05$ and relative risk $(\mathrm{RR})$ with $95 \%$ confidence interval), variables of each PIRO component that were significant for mortality were assigned a value of 1 . The cut-off score for predictor of mortality was calculated using the receiver operating characteristics (ROC) curve and the scores were stratified into three degrees of risk based on interquartile range, score $\leq \mathrm{Q} 1$ was categorized as low risk; Q1-Q3 was categorized as moderate risk; and score $>\mathrm{Q} 3$ was categorized as high risk.

Results: Out of the 80 subjects enrolled, 6 months- 5 years was the largest age group (56.3\%). The observed mortality was 15/80 (18.8\%). The modified PIRO severity score was compiled from significant variables of predisposition (malnutrition), insult (chest radiograph), response (hypoxemia, hypotension, CRP $>0.5 \mathrm{mg} / \mathrm{dL}, \mathrm{PCT}>0.5 \mathrm{ng} / \mathrm{dL}$ ) and organ dysfunction, with range of score $0-7$. Score $>3$ was categorized as a cut-off point score for predictor of mortality with AUC 0.919 (95\% CI 0.836-0.968), sensitivity of 80\%, and specificity of 84.62\%. Subjects with score $>3$ have RR of 10.544 compared to those with score $\leq 3$. The stratification of score level was low $(\leq 2)$, moderate $(3-4)$, and high $(5$ 7). The mortality levels were $0 \%, 46.7 \%$, and $53.3 \%$, respectively.

Conclusions: Modified PIRO severity score can be used as a sorting tool and predictor of mortality risk in children with pneumonia. This score can also be used to select candidates for intensive care, especially in health facilities with limited intensive care capacity.

Key words: Children; modified PIRO; pneumonia; severity score.

Correspondence: Heda Melinda N. Nataprawira, Department of Child Health, Faculty of Medicine, Universitas Padjadjaran /Dr. Hasan Sadikin General Hospital, Jalan Pasteur no. 28, Pasteur, Bandung 40161, Indonesia.

E-mail: heda_1155@yahoo.com

Contributions: VV, HMN, DS, contributed to the study conception and design, data collection and analysis; All the authors wrote the manuscript first draft, and made a substantive contribution to the manuscript. All the authors have read and approved the final version of the manuscript and agreed to be accountable for all aspects of the work.

Conflict of interest: The authors declare that they have no conflicts of interests.

Funding: Indonesia Endowment Fund for Education as a funder for this study. Funders are not involved in data analysis or manuscript preparation.

Availability of data and materials: The datasets used and/or analyzed during the current study are available from the corresponding author on reasonable request.

Ethics approval and consent to participate: This study was conducted after obtaining ethical clearance from Ethic Committee, Universitas Padjadjaran, West Java, Indonesia with registration number LB.02.01/X.6.5/285/2020. After a clear and detailed explanation of the purpose, risks, and benefit of the study, written informed consent was obtained from patient's parents which join the study in retrospective approach. 


\section{Introduction}

Pneumonia is the leading cause of death in children worldwide. More than 800.000 children under 5 years of age died of pneumonia in 2017 [1,2]. Clinical manifestations of pneumonia vary from mild to severe. Children with pneumonia may present with numerous signs and symptoms such as fever, cough, tachypnea, breathing difficulty, wheezing, headache, abdominal pain, and chest pain. Thorough assessments of clinical symptoms and risk factors are very important to determine outcome of the diseases and to identify children who require hospitalization and even intensive care [3]. Using a scoring system can help determine the severity of pneumonia. Many scoring systems have been widely used in adult patients, like Pneumonia Severity Index (PSI), CURB-65, CRB-65, SMART-COP, PIRO (predisposition, insult, response, organ dysfunction)[4-6]. However, there is little information available regarding scoring systems in children with pneumonia [6].

The PIRO (predisposition, insult, response, organ dysfunction) model has long been used for adult patients with sepsis [7]. The model was adopted to predict mortality in adult patients with community-acquired pneumonia requiring intensive hospitalization [4]. In 2016, PIRO was modified into a scoring system to be used in children with community-acquired pneumonia. This modified PIRO score consists of predisposition (age $<6$ months, comorbidity), insult (hypotension, hypoxia, bacteremia), response (multilobar or complicated pneumonia), and organ dysfunction. It can predict the risk of mortality in children with community-acquired pneumonia accurately. This score (0-10) can also be used to select patients who candidate for intensive care unit [8].

A study about severity score in pediatric pneumonia has never been carried out in Indonesia. As a consideration, the demographic characteristics of Indonesia (lower-middle-income country) are slightly different from the country in which previous studies were carried out (upper-middle-income country) [9]. Therefore, researchers would conduct the study to sort the severity of pneumonia in children and predict its risk of mortality. The researchers added several variables that have not been analyzed in the previous studies such as source of infection (community-acquired or nosocomial pneumonia), levels of C-reactive protein (CRP), and the levels of procalcitonin (PCT).

\section{Methods}

This ambispective cohort study was conducted in pneumonia patients from the age of 1 month to 18 years old, who were admitted at Hasan Sadikin Hospital from May to September 2020. This study was based on the medical records of pneumonia patients admitted in the above period and pneumonia patients hospitalized in August to September 2020 as well. In this study, pneumonia was defined as a lower respiratory tract infection characterized by fever, respiratory symptoms, and evidence of pulmonary parenchymal involvement based on physical examination or infiltrates on chest radiograph [10]. In this study, exclusion criteria were bronchiolitis, laryngitis, laryngotracheobronchitis, previous history of liver, kidney, and coagulation disorder. The drop-out criteria for the study were patients who returned home before the completion of the treatment and patients who died with a non-pneumonia cause.

Data were collected from history, physical examination, laboratory examination, and chest radiograph. All variables were determined based on operational definitions. Malnutrition was determined by weight/height ratio or body mass index for age $\leq 2 \mathrm{SD}$. Congenital heart diseases were confirmed by echocardiography.
Malignancy, human immunodeficiency virus (HIV) infection, steroid therapy (equal to prednisone at dose $2 \mathrm{mg} / \mathrm{kg}$ /day for more than 2 weeks), and immunosuppressant treatment were included to immunosuppression category. The source of pneumonia infection was divided into community-acquired (no history of hospitalization for 14 days before the onset of illness) or nosocomial (after 48 hours hospitalization).

Subjects were considered hypoxemic if oxygen saturation using oximetry was less than $90 \%$. Hypotension was defined as the systolic blood pressure below the $5^{\text {th }}$ percentile for age. Subjects were considered to have organ dysfunction (cardiovascular, hematological, respiratory, renal, liver, and neurological) based on the International Pediatric Sepsis Consensus Conference (IPSCC) diagnostic criteria [11]. Chest radiograph was divided into simple (lobar infiltrates) and complicated (multilobar infiltrates, empyema, and pleural effusions).

Descriptive data were presented in numbers and percentages for categorical data, while mean, standard deviation, median and range values for numeric data. Analysis calculation used chisquare statistical test to analyze the relationship between two cate-

Table 1. Baseline characteristics $(\mathbf{n}=\mathbf{8 0})$.

\begin{tabular}{|c|c|c|}
\hline Characteristics & No. of patients & $\%$ \\
\hline $\begin{array}{l}\text { Age (months) } \\
\quad \text { Median (range) }\end{array}$ & $23.5(1-210)$ & \\
\hline $\begin{array}{l}\text { Age group } \\
1 \text { month }-<6 \text { months } \\
6 \text { months }-5 \text { years } \\
\geq 5 \text { - } 18 \text { years }\end{array}$ & $\begin{array}{l}12 \\
45 \\
23\end{array}$ & $\begin{array}{c}15 \\
56.2 \\
28.8\end{array}$ \\
\hline $\begin{array}{l}\text { Gender } \\
\text { Male } \\
\text { Female }\end{array}$ & $\begin{array}{l}46 \\
34\end{array}$ & $\begin{array}{l}57.5 \\
42.5\end{array}$ \\
\hline $\begin{array}{l}\text { Comorbidity } \\
\text { Malnutrition } \\
\text { Congenital heart disease } \\
\text { Asthma } \\
\text { Immunosuppression }\end{array}$ & $\begin{array}{c}36 \\
14 \\
2 \\
23\end{array}$ & $\begin{array}{c}45 \\
17.5 \\
2.5 \\
28.8\end{array}$ \\
\hline $\begin{array}{c}\text { Source of infection } \\
\text { Community } \\
\text { Nosocomial }\end{array}$ & $\begin{array}{l}65 \\
15\end{array}$ & $\begin{array}{l}81.3 \\
18.8\end{array}$ \\
\hline $\begin{array}{l}\text { Clinical characteristics } \\
\text { Hypoxemia }\left(\mathrm{SpO}_{2}<90 \%\right) \\
\text { Hypotension }\end{array}$ & $\begin{array}{c}67 \\
9 \\
\end{array}$ & $\begin{array}{l}83.8 \\
11.3\end{array}$ \\
\hline $\begin{array}{l}\text { Organ dysfunction } \\
\text { Cardiovascular } \\
\text { Respiratory } \\
\text { Renal } \\
\text { Liver } \\
\text { Neurological } \\
\text { Hematological }\end{array}$ & $\begin{array}{c}21 \\
22 \\
3 \\
5 \\
7 \\
5\end{array}$ & $\begin{array}{r}26.3 \\
27.5 \\
3.8 \\
6.3 \\
8.8 \\
6.3\end{array}$ \\
\hline $\begin{array}{l}\text { Laboratory } \\
\text { Leukocytosis } \\
\text { Leukopenia } \\
\text { CRP }>0.5 \mathrm{mg} / \mathrm{dL} \\
\text { PCT }>0.5 \mathrm{ng} / \mathrm{mL} \\
\text { Positive bacterial blood culture }\end{array}$ & $\begin{array}{c}40 \\
7 \\
58 \\
22 \\
8\end{array}$ & $\begin{array}{c}50.0 \\
8.8 \\
72.5 \\
27.5 \\
10.0\end{array}$ \\
\hline $\begin{array}{l}\text { Chest radiograph } \\
\text { Simple } \\
\text { Complicated }\end{array}$ & $\begin{array}{c}74 \\
6\end{array}$ & $\begin{array}{c}92.5 \\
7.5\end{array}$ \\
\hline Mechanical ventilation & 10 & 12.5 \\
\hline Admission to intensive care unit & 12 & 15 \\
\hline Mortality & 15 & 18.8 \\
\hline
\end{tabular}


gorical data variables, or Fisher's exact test if there is a cell expectation value $<5$. Significant variables from each PIRO components $(p \leq 0.05)$ are given a score of 0 for those who are not at risk and 1 for those who are at risk. Then, RR was calculated with $95 \%$ confidence intervals to identify risk factor of mortality in children with pneumonia. Determination of cut-off point score was done and used as a predictor of mortality using ROC curve, then calculate the sensitivity and specificity were calculated. Stratification of severity score is based on median and interquartile range. Score of PIRO $\leq$ Q1 (lower quartile) is categorized as low risk; Q1-Q3 (interquartile range) moderate risk; $>\mathrm{Q} 3$ (upper quartile) high risk. Data analysis was performed using the SPSS program for Windows version 15.0 .

\section{Results}

During the study period, 80 subjects met the inclusion criteria. The characteristics of the subjects are listed in Table 1. Most of the subjects were male ( 46 of $80,57.5 \%$ ). The largest age group was 6 months-5 years $(56.3 \%)$. Malnutrition was the most common comorbidity among all subjects (moderate and severe malnutrition). Patients with malignancy, long-term steroids, taking immunosuppressive agent, autoimmune disease, and HIV infection were included in the immunosuppression category. Communityacquired pneumonia was more common than nosocomial pneumonia. The most common organ dysfunction suffered by patients was respiratory and cardiovascular dysfunction (shock) with a percentage of $27.5 \%$ and $26.3 \%$, respectively. Some subjects had more than 1 organ dysfunction concurrently. The study was conducted during the pandemic of coronavirus disease (COVID-19). Some subjects were tested on nasopharyngeal swab for the SARS-CoV2 polymerase chain reaction (PCR) as well. Out of the 80 subjects, 1 patient was confirmed COVID-19 and the subject was not included in the study group.

Distribution and relationship between each variable of PIRO model and mortality are summarized in Tables 2 and 3. Study showed that age, gender, and source of infection were not predictors for mortality in children with pneumonia. Malnutrition predicts mortality with RR 2.706 (95\% CI 1.018-7.193). Clinical manifestations of hypoxemia and hypotension were predictors of mortality with RR 6.382 (95\% CI 0.405-100.522) and RR 9.016 (95\% CI 4.300-18.902), respectively. Overall, organ dysfunction (cardiovascular, respiratory, renal, liver, neurologic, and hematologic) was a predictor of mortality. Some subjects suffered from multiple organ dysfunction simultaneously. All children with 1 organ dysfunction was recovered and discharged with improvement. The mortality of subjects with 2 organs dysfunction was $67 \%$ (6 of 9 patients), mortality in 3 organs dysfunction was $80 \%$ (4 of 5 patients), whereas all patients who had 4 and 5 organs dysfunction came to death. Significant laboratory variables were the increase in CRP and PCT levels. We used CRP value of $>0.5$ $\mathrm{mg} / \mathrm{dL}$ and PCT value of $>0.5 \mathrm{ng} / \mathrm{dL}$. These values are adjusted to the tools used in our laboratory facilities (Siemens Dimension EXL 200 for CRP and ADVIA Centaur BRAHMS PCT for PCT). Complicated findings on chest radiograph were predictor of mortality in children with pneumonia as well. We found positive blood culture on $10 \%$ subjects ( 8 out of 80 ) and the resulting bacteria were of Staphylococcus hominis, S. epidermidis, and S. haemolyticus. In this study, we only checked for bacterial culture.

Table 2. Relationship of variables of PIRO with mortality in children with pneumonia.

\begin{tabular}{|c|c|c|c|c|c|}
\hline & & me & & & \\
\hline Variable & $\begin{array}{c}\text { Survivors } \\
(\mathrm{n}=65)\end{array}$ & $\begin{array}{c}\text { Deceased } \\
(n=15)\end{array}$ & $\mathbf{p}$ & $\mathbf{R R}$ & $95 \%$ CI \\
\hline $\begin{array}{l}\text { Age } \\
1 \text { month }-<6 \text { months } \\
6 \text { months }-<5 \text { years } \\
\geq 5 \text { years }\end{array}$ & $\begin{array}{l}10 \\
37 \\
18\end{array}$ & $\begin{array}{l}0.906 \\
2 \\
8 \\
5\end{array}$ & & $\begin{array}{l}0.872 \\
0.889 \\
1.239\end{array}$ & $\begin{array}{l}0.225-3.384 \\
0.357-2.215 \\
0.475-3.230\end{array}$ \\
\hline $\begin{array}{l}\text { Gender } \\
\text { Male } \\
\text { Female }\end{array}$ & $\begin{array}{l}37 \\
28\end{array}$ & $\begin{array}{l}9 \\
6\end{array}$ & 0.828 & $\begin{array}{c}1.109 \\
1.0\end{array}$ & $0.436-2.819$ \\
\hline $\begin{array}{l}\text { Comorbidity } \\
\text { Malnutrition } \\
\text { Congenital heart disease } \\
\text { Asthma } \\
\text { Immunosuppression }\end{array}$ & $\begin{array}{c}24 \\
11 \\
2 \\
17\end{array}$ & $\begin{array}{l}10 \\
3 \\
0 \\
6\end{array}$ & $\begin{array}{c}0.036 \\
0.720 \\
1.0 \\
0.346\end{array}$ & $\begin{array}{l}2.706 \\
1.179 \\
0.849 \\
1.652\end{array}$ & $\begin{array}{c}1.018-7.193 \\
0.382-3.634 \\
0.065-11.092 \\
0.663-4.115\end{array}$ \\
\hline $\begin{array}{c}\text { Source of infection } \\
\text { Community } \\
\text { Nosocomial }\end{array}$ & $\begin{array}{l}53 \\
12\end{array}$ & $\begin{array}{c}12 \\
3\end{array}$ & 1.00 & $\begin{array}{c}1.0 \\
1.083\end{array}$ & $0.349-3.366$ \\
\hline $\begin{array}{l}\text { Clinical characteristics } \\
\text { Hypoxemia } \\
\text { Hypotension } \\
\text { Organ dysfunction (combined) } \\
\text { Cardiovascular } \\
\text { Respiratory } \\
\text { Renal } \\
\text { Liver } \\
\text { Neurologic } \\
\text { Hematologic }\end{array}$ & $\begin{array}{c}52 \\
1 \\
11 \\
7 \\
7 \\
0 \\
0 \\
2 \\
0\end{array}$ & $\begin{array}{c}15 \\
8 \\
10 \\
14 \\
15 \\
3 \\
5 \\
5 \\
5\end{array}$ & $\begin{array}{c}0.052 \\
<0.001 \\
<0.001 \\
<0.001 \\
<0.001 \\
0.006 \\
<0.001 \\
0.002 \\
<0.001\end{array}$ & $\begin{array}{c}6.382 \\
9.016 \\
5.619 \\
39.333 \\
79.522 \\
6.417 \\
7.500 \\
5.214 \\
7.500\end{array}$ & $\begin{array}{c}0.405-100.522 \\
4.300-18.902 \\
2.171-14.544 \\
5.503-281.121 \\
4.960-1275.02 \\
3.815-10.791 \\
4.212-13.355 \\
2.482-10.954 \\
4.212-13.355\end{array}$ \\
\hline
\end{tabular}


Table 3. Relationship between laboratory, chest radiograph, and complications with mortality in children with pneumonia.

\begin{tabular}{|c|c|c|c|c|c|}
\hline \multirow[b]{2}{*}{ Variable } & \multicolumn{2}{|c|}{ Outcome } & \multirow[b]{2}{*}{$\mathbf{p}$} & \multirow[b]{2}{*}{$\mathbf{R R}$} & \multirow[b]{2}{*}{$95 \%$ CI } \\
\hline & $\begin{array}{l}\text { Survivors } \\
(\mathrm{n}=65)\end{array}$ & $\begin{array}{c}\text { Deceased } \\
(n=15)\end{array}$ & & & \\
\hline \multicolumn{6}{|l|}{ Laboratory examination } \\
\hline Leukocytosis & 32 & 8 & 0.775 & 1.143 & $0.458-2.853$ \\
\hline Leukopenia & 6 & 1 & 100 & 0.745 & $0.114-4.856$ \\
\hline $\mathrm{CRP}(>0,5 \mathrm{mg} / \mathrm{mL})$ & 44 & 14 & 0.045 & 5.310 & $0.742-38.023$ \\
\hline PCT $(>0,5 \mathrm{ng} / \mathrm{mL})$ & 11 & 11 & $<0.001$ & 7.250 & $2.578-20.386$ \\
\hline Chest radiograph & & & 0.076 & & \\
\hline Simple & 62 & 12 & & 1.0 & 1.0 \\
\hline Complicated & 3 & 3 & & 3.083 & $1.189-7.998$ \\
\hline \multicolumn{6}{|l|}{ Other variables } \\
\hline Positive bacterial blood culture & 7 & 1 & 1.00 & 0.643 & $0.097-4.267$ \\
\hline Mechanical ventilation & 3 & 7 & $<0.001$ & 6.125 & $2.841-13.203$ \\
\hline Admission to intensive care unit & 5 & 7 & 0.004 & 4.958 & $2.211-11.120$ \\
\hline
\end{tabular}

\section{Modified PIRO severity score}

As shown in Tables 2 and 3, the significant variables of PIRO were predisposition (malnutrition), insult (complicated chest radiograph), response (hypoxemia, hypotension, CRP $>0.5 \mathrm{mg} / \mathrm{dL}$, PCT $>0.5 \mathrm{ng} / \mathrm{dL}$ ), and organ dysfunction. These significant variables were given a value of 0 (for those which are not at risk) and 1 (for those at risk). Thus, a scale of 0-7 modified PIRO severity score was created (Table 4). Furthermore, we used curve receiver operating characteristics (ROC) to determine the cut-off point score as a predictor of mortality in children with pneumonia; the results were cut-off point $>3$ with area under the curve (AUC) 0.919 (95\% CI 0.836-0.968), with sensitivity $80 \%$ and specificity $84.62 \%$ (Figure 1 ). The relationship between cut-off point modified PIRO severity score with mortality in children with pneumonia is presented in Table 5. The mortality risk of subjects with score $>3$ was 10.544 times higher compared to subjects with scores $\leq 3$; based on median and interquartile range of the score set (0-7), where Q1 (lower quartile) is 1.25; Q1-Q3 (interquartile range) is 4.5; Q3 (upper quartile) is 5.75. The score can be stratified into three levels of risk: low $(\leq 2)$, moderate (3-4), and high (5-7). All subjects were distributed in each level: low risk (41 patients/51.2\%), moderate risk (29 patients/36.2\%), and high risk (10 patients/12.5\%). No low-risk subjects died, while as many as 7 moderate-risk subjects died (46.7\%), and 8 high-risk subjects died (53.3\%).

Table 4. Modified PIRO score.

\begin{tabular}{ll} 
& Variables \\
Predisposition & Malnutrition \\
Insult & Complicated chest radiograph \\
\hline Response & Hypoxemia \\
& Hypotension \\
& CRP $>0.5 \mathrm{mg} / \mathrm{dL}$ \\
& PCT $>0.5 \mathrm{ng} / \mathrm{dL}$ \\
Organ dysfunction & Organ dysfunction. \\
\hline
\end{tabular}
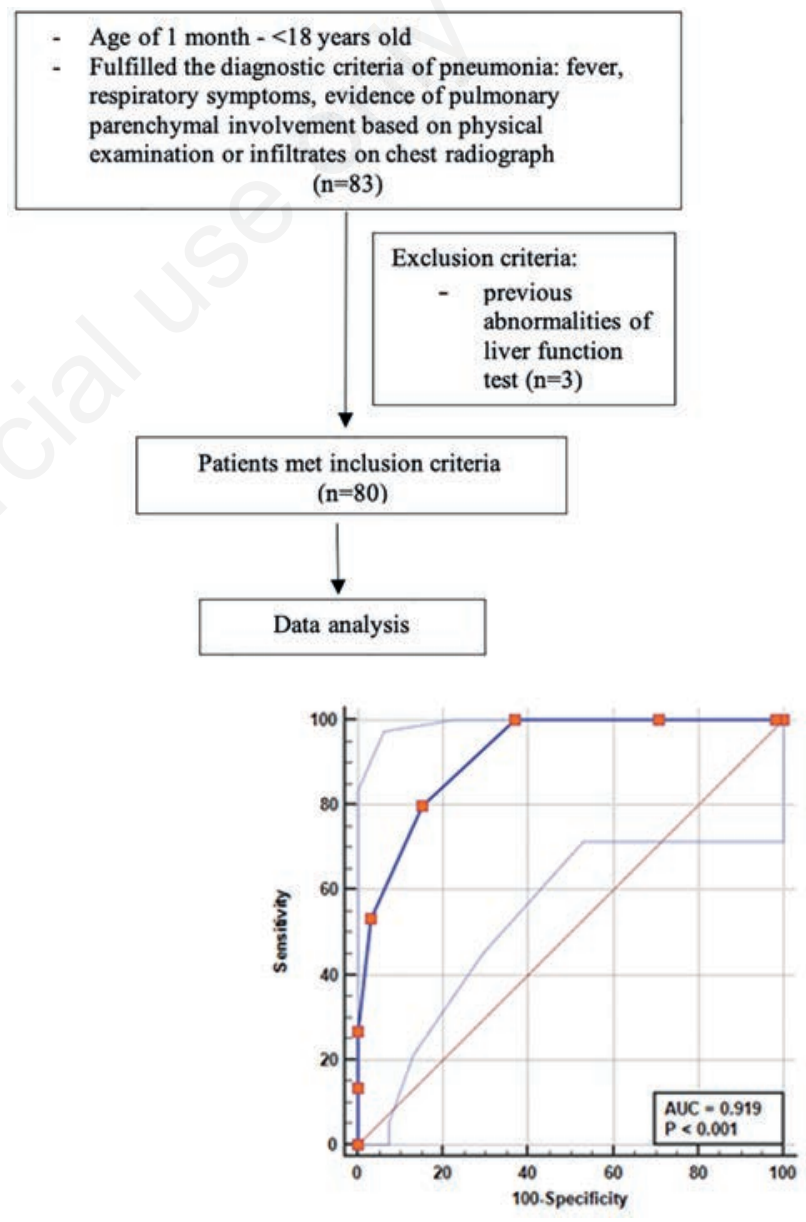

Figure 1. Cut-off point modified PIRO severity score $(>3)$ as predictor of mortality in children with pneumonia - ROC curve.

Table 5. Relationship between cut-off point modified PIRO severity score with mortality in children with pneumonia

\begin{tabular}{|c|c|c|c|c|c|}
\hline \multirow[b]{2}{*}{ Cut-off point } & \multicolumn{2}{|c|}{ Outcome } & \multirow[b]{2}{*}{$\underset{(n=15)}{p}$} & \multirow[b]{2}{*}{$\mathbf{R R}$} & \multirow[b]{2}{*}{$95 \%$ CI } \\
\hline & Deceased & $\begin{array}{c}\text { Survivors } \\
(\mathrm{n}=65)\end{array}$ & & & \\
\hline$>3$ & 12 & 10 & $<0001$ & 10.544 & $3.286-33.845$ \\
\hline$\leq 3$ & 3 & 55 & & & \\
\hline
\end{tabular}




\section{Discussion}

The results showed that the mortality rate for children with pneumonia was quite high, namely $18.8 \%$. This study was conducted at national referral hospital during the COVID-19 pandemic. The number of pneumonia patient's visits decreased during the pandemic. However, referred patients usually presented with more severe clinical conditions. Some of deceased subjects were accompanied by other comorbidities such as malignancy (4 patients with leukemia), autoimmune disease ( 2 patients with systemic lupus erythematosus), and HIV infection (2 patients). All diseases were included into immunosuppression state. We consider it can affect the mortality rate as stated in a previous study [12]. Not all of the variables analyzed as predictors of mortality are comparable to those of a previous study [8]. We found that age was not a significant predisposition variable; in contrast to Araya who included age $<6$ months in his PIRO study [8]. In Respiratory Index of Severity in Children (RISC) system score among young children with respiratory infections in South Africa, the age variable is only significant in HIV-infected patients and not significant in patients who are not infected with HIV [13]. It supports several previous studies that did not find age as a predictor of mortality in child with pneumonia $[14,15]$. We consider that the decreasing number of pneumonia cases that came to our hospital during the pandemic of COVID-19 can affect the significance of age variable.

Several previous studies have shown that the male gender is a protective factor and vice versa, female gender has higher risk for severe pneumonia, but not in other studies [16-18]. We did not find that gender affects mortality in pediatric pneumonia. Likewise, Araya's Modified PIRO score also does not include the gender variable as a component of the score. Malnutrition was the only significant comorbidity for mortality. Patients were considered malnourished from the interpretation of $\mathrm{BW} /$ height or $\mathrm{BMI} / \mathrm{U} \leq 2$ SD according to the World Health Organization's growth charts $[19,20]$. Our finding is in line with a previous study which concluded that malnutrition as a risk factor for severe pneumonia [21]. Malnutrition in children with severe pneumonia was associated with reduced metabolic capacity to cope with physiological and psychological responses to an infection such as an increase in temperature, cardiac output and respiratory effort [22]. As a consequence, the presence of malnutrition increases the risk of death in this patient. Some of the subjects had congenital heart disease as a comorbidity which was confirmed by echocardiography. The most common heart defects are persistent ductus arteriosus, atrial septal defect and ventricular septal defect and it was not a significant predictor of mortality.

Overall, organ dysfunction significantly affects the mortality of children with pneumonia. Menendez et al. conducted a study on organ dysfunction in adult patients with pneumonia, with the conclusion that the number of organs dysfunction has an effect on mortality within 30 days [23]. It has also been seen in this study that the more organs with dysfunction, the higher risk of mortality. The most common etiology of pneumonia associated with sepsis and multiple organ dysfunctions is Streptococcus pneumonia [24]. However, this microorganism was not identified from all positive blood cultures. Staphylococcus hominis, S. epidermidis, and S. haemolyticus identified in positive blood culture were normal skin flora of the human skin body, especially axillary, perineal and inguinal areas. Therefore, we consider possible contaminants in blood culture samples.

Hypoxemia (oxygen saturation $<90 \%$ ) is a cardinal sign in pneumonia patients. Delay detection of hypoxemia is associated with a worse outcome of pneumonia. Blot et al. conducted a study on adult patients with pneumonia who were admitted to the intensive care unit and concluded that a 1-hour delay in detection of hypoxemia would increase the mortality rate from $26 \%$ to $36 \%[25]$. A study conducted in Papua New Guinea proves that hypoxemia can potentially increase the risk of mortality in children [26]. The introduction of oximetry to detect hypoxemia in pneumonia patients is becoming a solution that can reduce child mortality in developing countries [27].

Hypotension is a determinant of uncompensated septic shock. Hypotension frequently constitutes one of the prominent features of shock, but could be a late sign in pediatric patients. Previously, healthy children with intact cardiovascular homeostatic mechanisms can compensate extremely well during hypoperfusion states for relatively long periods without triggering ischemia in the myocardial cells. Contrary to adult patients, hypotension appears at a longer time in children and indicates non-reversible cardiovascular collapse [28,29]. This will affect regulation of the host response to an infection and will ultimately increase risk of mortality in the patient. In line with Araya et al., hypotension in children with pneumonia increases the risk of mortality by 48.7 times [8].

Increased levels of CRP and PCT were shown to be good predictors of mortality. This is in line with Yadav et al., namely that CRP and PCT have a linear positive correlation with the severity of pneumonia [30]. Wu et al. concluded that increased levels of CRP are closely associated with bacterial infection and severe pneumonia [31]. Increased levels of CRP together with other parameters can be used as predictors for the development of severe pneumonia. However, the usefulness of a single CRP level is still limited. Akech et al. in Kenya concluded that children with signs of pneumonia or sign of bacterial infection would have had higher levels of PCT [32]. Procalcitonin associated with severity of the disease and administration of antibiotics based on the levels of PCT can be used at the time of unavailability of blood culture.

In this study, 7 out of 12 patients $(58 \%)$ treated in the intensive care unit died. Limited bed capacity in pediatric intensive care unit delimitaded the number of patients who could receive intensive care management. Not all intensive care candidates could be transferred immediately to intensive care unit. Some patients had to be confined in resource-limited wards in our hospital before admitted to the intensive care unit. This study was conducted at the time of the COVID-19 pandemic. Several patients had throat swabs examined for SARS-CoV-2 and there was 1 patient with confirmed COVID-19. The patient was a consult patient from the Pediatric Surgery Department who planned for surgery of diaphragmatic hernia but the patient had bronchopneumonia. Then, the patient was treated in a COVID-19 isolation room. After 2 times of negative throat swabs within 24 hours interval since the first examination, the patient was allowed to leave the isolation room and undergo the surgery.

We formed a model of severity score from PIRO variables which is suitable to characteristics of our patients in general. Several previous studies that adapted PIRO concept as a severity score have different ranges. Rello et al. provides a range of $0-8$ for PIRO score in adult patients with community-acquired pneumonia who were admitted to the intensive care unit, while Araya et al. provides a range of 0-0 for PIRO score in children with pneumonia $[4,8]$.

There are several limitations of this study. It was carried out during the COVID-19 pandemic, in which the number of cases of pneumonia pediatric decreased. These circumstances would have not described the data as usual. This study uses ambispective method in consideration of limited time availability. Most of the study subjects were taken from medical records, so it is possible that the examination standards are not equal for all subjects. 
Further studies with prospective methods can be carried out at a later date for the validity of the modified PIRO severity score variable which is more significant in pediatric pneumonia patients in Indonesia.

\section{Conclusions}

This modified PIRO severity score can be used for sorting the severity of pneumonia in children and predicting its risk of mortality. The stratification of risk level in this study can help health workers in selecting appropriate management for patients, especially for health facilities with limited intensive care unit capacities.

\section{Acknowledgements}

The Authors express their gratitude to Hadyana Sukandar for statistical analysis support and thank the Indonesia Endowment Fund for Education as a funder for this study.

\section{Abbreviations \\ BMI: body mass index; \\ COVID-19: Coronavirus Disease 2019; \\ CRB-65: confusion, respiratory rate, blood pressure, age $>65$; \\ CRP: $\quad$ C-reactive protein \\ CURB-65: confusion, urea, respiratory rate, blood pressure, age $>65$; \\ HIV: $\quad$ Human Immunodeficiency Virus; \\ PCR: $\quad$ polymerase chain reaction; \\ PCT: $\quad$ procalcitonin; \\ PIRO: $\quad$ predisposition, insults, response, organ dysfunction; \\ PSI: $\quad$ Pneumonia Severity Index; \\ RISC: $\quad$ Respiratory Index of Severity in Children; \\ SARS-CoV-2: severe acute respiratory syndrome coronavirus 2; \\ SMART-COP: systolic blood pressure, multilobar chest radiography, albumin level, respiratory rate, tachycardia, confusion, oxygenation, dan arterial $\mathrm{pH}<7.35$.}

\section{References}

1. WHO. Pneumonia. 2019. Accessed: 21 September 2020. Available from: https://www.who.int/news-room/factsheets/ detail/pneumonia/

2. UNICEF. Pneumonia. 2019. Accessed: 2 September 2020. Available from: https://data.unicef.org/topic/child-health /pneumonia/

3. Arbo A, Lovera D, Martínez-cuellar C. Mortality predictive scores for community-acquired pneumonia in children. Curr Infect Dis Rep 2019;21:1-8.

4. Rello J, Rodriguez A, Lisboa T, Gallego M, Lujan M, Wunderink R. PIRO score for community-acquired pneumonia: A new prediction rule for assessment of severity in the intensive care unit patients with community-acquired pneumonia. Crit Care Med 2009;37:456-62.

5. Niederman MS, Feldman C, Richards GA. Combining information from prognostic scoring tools for CAP: An American view on how to get the best of all worlds. Eur Respir J
2006;27:9-11.

6. Uwaezuoke SN, Come AC. Prognostic scores and biomarkers for pediatric community-acquired pneumonia: how far have we come? Ped Health Med and Therap 2017;8:9-18.

7. Marshall JC. The PIRO (predisposition, insult, response, organ dysfunction) model toward a staging system for acute illness. Virulence 2014;5:27-35.

8. Araya S, Lovera D, Zarate C, Apodaca S, Acuna J, Sanabria G, et al. Application of a prognostic scale to estimate the mortality of children hospitalized with community-acquired pneumonia. Pediatr Infect Dis J 2016;35:369-73.

9. United Nations. World economic situation and prospects. 2019. Accessed: 2 September 2020. Available from: https://www.un.org/development/desa/dpad/publication/world -economic-situation-and-prospects-2019/

10. Gereige RS, Laufer PM. Pneumonia. Pediatr Rev 2013;34:438-56.

11. Goldstein B, Giroir B, Randolph A. International pediatric sepsis consensus conference: Definitions for sepsis and organ dysfunction in pediatrics. Pediatr Crit Care Med 2005;6:2-8.

12. Zar HJ. Pneumonia in HIV-infected and HIV-uninfected children in developing countries: Epidemiology, clinical features, and management. Curr Opin Pulm Med 2004;10:176-82.

13. Reed C, Madhi SA, Klugman KP, Kuwanda L, Ortiz JR, Finelli L, et al. Development of the Respiratory Index of Severity in Children (RISC) score among young children with respiratory infections in South Africa. PLoS One 2012;7:1-8.

14. Ibraheem RM, Abdulkadir MB, Gobir AA, Johnson WBR. Socio-demographic and clinical factors predicting time to presentation for children with pneumonia in Ilorin, Nigeria. Alexandria J Med 2018;54:247-50.

15. Bokade CM, Madhura AD, Bagul AS, Thakre SB. Predictors of mortality in children due to severe and very severe pneumonia. Niger Med J 2015;56:287-91.

16. Atwa ZT. Usefulness of gender and abnormal blood count for predicting pneumonia outcome in children. Egypt J Chest Dis Tuberc 2015;64:169-74.

17. Fonseca da Lima EJ, Mello MJG, Albuquerque M de FPM de, Lopes MIL, Serra GHC, Lima DEP, et al. Risk factors for community-acquired pneumonia in children under five years of age in the post-pneumococcal conjugate vaccine era in Brazil: A case control study. BMC Pediatr 2016;16:1-9.

18. Amorim PG, Morcillo AM, Tresoldi AT, Fraga A de MA, Pereira RM, Baracat ECE. Factors associated with complications of community-acquired pneumonia in preschool children. J Bras Pneumol 2012;38:614-21.

19. WHO. Child Growth Standards. Geneva: World Health Otganization; 2006.

20. de Onis M, Onyango AW, Borghi E, Siyam A, Nishida C, Siekmann J. Development of a WHO growth reference for school-aged children and adolescents. Bull World Health Organ 2007;85:660-7.

21. Hadisuwarno W, Setyoningrum RA, Umiastuti P. Host factors related to pneumonia in children under 5 years of age. Paediatr Indones 2015;55:248-51.

22. Ginsburg AS, Izadnegahdar R, Berkley JA, Walson JL, Rollins N, Klugman KP. Undernutrition and pneumonia mortality. Lancet Glob Health 2015;3:735.6.

23. Menendez R, Montull B, Reyes S, Amara-Elori I, Zalacain R, Capelastegui A, et al. Pneumonia presenting with organ dysfunctions: Causative microorganisms, host factors and outcome. J Infect 2016;73:419-26.

24. Andonegui G, Goring K, Liu D, McCafferty DM, Winston BW. Characterization of S. pneumoniae pneumonia-induced multi- 
ple organ dysfunction syndrome: An experimental mouse model of gram-positive sepsis. Shock 2009;31:423-8.

25. Blot SI, Rodriguez A, Solé-Violán J, Blanquer J, Almirall J, Rello J. Effects of delayed oxygenation assessment on time to antibiotic delivery and mortality in patients with severe community-acquired pneumonia. Crit Care Med 2007;35:2509-14.

26. Duke T, Mgone J, Frank D. Hypoxaemia in children with severe pneumonia in Papua New Guinea. Int $\mathrm{J}$ Tuberc Lung Dis 2001;5:511-9.

27. Duke T, Subhi R, Peel D, Frey B. Pulse oximetry: Technology to reduce child mortality in developing countries. Ann Trop Paediatr 2009;29:165-75.

28. Kleinman ME, Chameides L, Schexnayder SM, Samson RA, Hazinski MF, Atkins DL, et al. Pediatric advanced life support: 2010 American Heart Association guidelines for cardiopulmonary resuscitation and emergency cardiovascular care. Pediatrics 2010;126:1-41.
29. Weiss SL, Peters MJ, Alhazzani W, Agus MSD, Flori HR, Inwald DP, et al. Surviving sepsis campaign international guidelines for the management of septic shock and sepsis-associated organ dysfunction in children. Intensive Care Med 2020:46:10-67.

30. Yadav KK, Awasthi S, Takia L, Agarwal J, Agarwal GG. Procalcitonin and C-reactive protein in WHO defined severe and very severe community acquired pneumonia: A hospital based cross-sectional study. Clin Epidemiol Glob Health 2015;3:3-9.

31. Wu J, Jin Y, Li H, Xie Z, Li J, Ao Y, et al. Evaluation and significance of $\mathrm{C}$-reactive protein in the clinical diagnosis of severe pneumonia. Exp Ther Med 2015;10:175-80.

32. Akech SO, Kinuthia DW, Macharia W. Serum procalcitonin levels in children with clinical syndromes for targeting antibiotic use at an emergency department of a Kenyan Hospital. J Trop Pediatr 2020;66:29-37.

Received for publication: 9 November 2020. Accepted for publication: 19 February 2021.

This work is licensed under a Creative Commons Attribution-NonCommercial 4.0 International License (CC BY-NC 4.0).

CC Copyright: the Author(s), 2021

Licensee PAGEPress, Italy

Multidisciplinary Respiratory Medicine 2021; 16:735

doi:10.4081/mrm.2021.735 